\title{
The 2013 Curriculum Implementation Review The Pedagogical Competence And Mastery Of Information And Communication Technology Teachers At SD Negeri
}

\author{
Dido Wendi \\ Program Pasca Sarjana Universitas Terbuka, Indonesia \\ e-mail: didowendi@gmail.com
}

\begin{abstract}
This study aims to analyze the teacher's Pedagogical and technology competence in the implementation of the Curriculum 2013. The research used a descriptive qualitative approach. Implementation of the Curriculum 2013 includes dimensions of curriculum concepts, procurement of books, learning activities, and learning assessment. Implementation of the Curriculum 2013 in terms of teacher pedagogics includes nine aspects. The implementation of the Curriculum 2013 in terms of mastery of information and communication technology teachers includes 1) ICTs used, 2) Development activities of subject matter using ICTs, 3) forms of use of it. Implementation of the 2013 Curriculum accommodates student learning needs. The provision of books is following the provisions. Student learning activities are student-centered. The assessment shows an emphasis on authentic attitude and knowledge assessment. The implementation of the Curriculum 2013 in the dimension of teachers' pedagogical competence in the good category. The implementation of the 2013 curriculum in the dimensions of ICT mastery by teachers based on interview data, questionnaires, and observations is quite well categorized in terms of the technology used, the activities of using ICT, and its use as a learning medium.
\end{abstract}

Keywords: Curriculum implementation; Pedagogical competence; ICT Mastery

\section{PENDAHULUAN}

Dinamika pendidikan Indonesia mengalami fluktuasi. Sejak kemerdekaan hingga kini kurikulum pendidikan Indonesia mengalami pergantian sepuluh kali. UndangUndang No. 20 Tahun 2003 tentang Sistem Pendidikan Nasional menyatakan tujuan Pendidikan Nasional adalah mengembangkan potensi peserta didik beriman dan bertaqwa, berakhlak mulia, sehat, berilmu, cakap, kreatif, mandiri serta bertanggung jawab. Pemerintah merealisasikannya melalui penyusunan dan implementasi kurikulum pengembangan karakter yang juga merupakan nilai-nilai luhur bangsa (Undang-Undang Nomor 20 Tahun 2003 tentang Sistem Pendidikan Nasional, n.d.). Kurikulum 2013 pada tahapan implementasinya dilaksanakan bersifat tematik integratif. Tematik integratif adalah proses pembelajaran dimana materi bukan dibelajarkan per-mata pelajaran melainkan melalui tema yang menggabungkan indikatorindikator mata pelajaran yang relevan dengan tema. Kurikulum 2013 melibatkan peserta didik dalam proses pembelajaran bertujuan memberikan kesempatan mengembangkan diri dan membentuk kompetensi serta potensi naturalnya. Untuk tujuan tersebut dibutuhkan personal guru yang kreatif dan berkemampuan menyesuaikan kompetensi yang dibutuhkan bagi pembelajaran peserta didik. Kompetensi guru yang demikian akan berdampak pada sikap, pengetahuan dan keterampilan peserta didik dalam proses pembelajaran. Penerapan kompetensi pedagogik menuntut tersedianya 
sumber belajar yang memadai. Menghadirkan sumber belajar ke dalam kelas dapat dilakukan dengan menghadirkan narasumber langsung, program audio, atau visualisasi sumber belajar. Teknologi informasi dan komunikasi seperti laptop, gadget, personal komputer, audio set, projector, dan akses internet menjadi jendela dunia sekaligus media belajar. Implementasi Kurikulum 2013 tingkat pendidikan dasar dilaksanakan bertahap di kelas 1 dan 4. Empat tahun kemudian, Kurikulum 2013 diimplementasikan dari kelas 1 sampai dengan kelas 6. Namun kompetensi pedagogik guru belum terealisasi secara penuh pada implementasi Kurikulum 2013. Kompetensi pedagogik tersebut meliputi pengelolaan, perancangan dan pelaksanaan, evaluasi, dan pengembangan potensi peserta didik (Mulyasa, 2008). Berdasarkan pemaparan tersebut, tujuan studi ini adalah 1) Menganalisis kompetensi pedagogik guru dalam implementasi Kurikulum 2013 di SD Negeri; dan 2) Menganalisis penguasaan teknologi informasi dan komunikasi guru dalam implementasi Kurikulum 2013 di SD Negeri.

Kebijakan adalah bentuk aturan kehidupan bersama yang harus ditaati dan berlaku mengikat seluruh warganya (Nugroho, D, 2003). Wiliam Dunn mengelompokkan ciri pokok kebijakan ke dalam empat kelompok yaitu, subjektivitas, sifat bantuan, dan dinamika masalah kebijakan (Anggara, 2014).

Kurikulum adalah sesuatu yang disiapkan untuk membangun kehidupan bangsa, masyarakat, dan individu (Bughin, Manyika, \& Woetzel, 2016). Empat dimensi konsep dan teori kurikulum adalah kurikulum sebagai sebuah ide, kurikulum sebagai dokumen tertulis, kurikulum sebagai proses kegiatan pembelajaran, dan kurikulum sebagai hasil belajar (Hasan, 2015). Tiga peran kurikulum yaitu peran konservatif, kreatif, dan kritis evaluatif (Muzamiroh, 2013).

Implementasi atau penerapan adalah serangkaian kegiatan dalam rangka memberikan kebijakan publik, sehingga kebijakan membawa hasil sesuai harapan (Syaukani, 2004). Implementasi kebijakan berkaitan dengan kegiatan yang diarahkan untuk merealisasikan yang mana eksekutif mengorganisasi, menginterpretasi, dan menerapkan kebijakan yang telah diseleksi.
Implementasi kebijakan dipengaruhi oleh empat variabel yaitu komunikasi, sumber daya, diposisi, dan struktur birokrasi (Patton \& Sawicki, 1993).

Kompetensi adalah penguasaan terhadap seperangkat pengetahuan, keterampilan, nilainilai dan sikap mengarah pada kinerja dan direfleksikan dalam kebiasaan berpikir dan bertindak sesuai dengan profesinya (Wibowo., 2007). Kompetensi pedagogik adalah kemampuan guru dalam mengelola proses pembelajaran peserta didik.

Beberapa hasil penelitian yang relevan serta memiliki korelasi dengan penelitian yang dilaksanakan diantaranya adalah:

1. Penelitian Kompetensi Pedagogik Guru dalam Implementasi Kurikulum 2013 SD Se-Kecamatan Kasihan Bantul Yogyakarta oleh Herlini Melianasari pada 2015. Masalah yang dikaji adalah kompetensi pedagogik guru dalam Implementasi Kurikulum 2013 SD Se-Kecamatan Kasihan Bantul Yogyakarta. Hasil penelitian ini 79\% guru mampu/menguasai pedadogi, $13 \%$ sangat mampu, $8 \%$ cukup mampu, dan $0 \%$ tidak berkemampuan pedagogik (Melianasari, 2015).

2. Penelitian tentang Hambatan-hambatan Pelaksanaan Kurikulum 2013 di SMK Negeri 1 Seyegan Yogyakarta dilaksanakan oleh Ivan Prasetyo N. pada 2015. Penelitian tersebut menggunakan mix method. Hasil penelitian menunjukkan kendala dari perencanaan pembelajaran terutama pada indikator pendesainan pembelajaran yang berorientasi pada peserta didik mendapatkan skor 13,5. Indikator siswa aktif dalam proses pembelajaran dari proses pelaksanaan pembelajaran, hambatan guru pada skor 13,00. Dengan kategori cukup banyak hambatan. Hambatan perencanaan proses pembelajaran di skor 13,43 kategori cukup banyak hambatan terutama pada indikator penilaian secara lengkap, detail, dan menyeluruh.

3. Studi kompetensi guru dalam memanfaatkan media pembelajaran berbasis teknologi informasi dan komunikasi di SD Negeri 01 Ledok Kecamatan Sambong Kabupaten Blora dilaksanakan oleh Aditiya Niarsa pada 2013. Hasil penelitian yang didapat adalah kompetensi guru dalam 
merancang media pembelajaran mendapatkan rata-rata skor 24,7 dengan kategori cukup, kompetensi guru dalam memproduksi media pembelajaran mendapatkan rata-rata skor 22,7 dengan katagori cukup, dan kompetensi guru dalam memanfaatkan media pembelajaran mendapatkan rata-rata skor 29,72 dengan kategori baik (Niarsa, 2013).

\section{METODE}

Penelitian ini dilakukan dengan menggunakan metode kualitatif deskriptif. Pengumpulan data dilakukan secara gabungan antara Indepth Interview, observasi, dan penyebaran angket. Analisis data bersifat induktif dengan menekankan kebermaknaan.

Subjek penelitian adalah seluruh guru aktif yang bertugas di SD Negeri. Subjek penelitian adalah seluruh guru yang berjumlah 33 orang, baik guru kelas maupun guru mata pelajaran disebabkan fokus kajian penelitian adalah kemampuan pengelolaan pembelajaran dan pemanfaatan teknologi informasi dan komunikasi dalam implementasi Kurikulum 2013. Kualifikasi pendidikan yang dimiliki oleh ke-33 guru tersebut adalah Strata 2 Magister Pendidikan Agama Budha satu Orang, Strata 1 Sarjana Pendidikan Guru Sekolah Dasar (PGSD) 21 0rang, Strata 1 Sarjana Pendidikan Agama Islam dua orang, Strata 1 Sarjana Theologia satu orang, Strata 1 Sarjana Penjaskes satu orang, Diploma II Pendidikan Guru Sekolah Dasar dua orang, dan lima orang tamatan SLTA. Instrumen penelitian pada penelitian kualitatif adalah peneliti sendiri.

\section{TEMUAN DAN PEMBAHASAN}

\section{Implementasi Kurikulum 2013 Dimensi Konsep Kurikulum, Pengadaan Buku, Aktivitas Belajar dan Penilaian Pembelajaran di SD Negeri}

Responden menjelaskan bahwa konsep Kurikulum 2013 sesuai dengan standar kompetensi lulusan SD Negeri yang didasarkan pada kebutuhan siswa. Kompetensi dimaksud adalah standar kompetensi lulusan yang bebas mata pelajaran dan secara umum mengarah pada pembentukan karakter siswa. Pengadaan buku guru dan buku siswa sudah lengkap sangat menunjang proses pembelajaran. Proses pembelajaran menerapkan pendekatan saintifik dan penugasan dalam proses pembelajaran.

Pernyataan guru tersebut sesuai dengan hasil angket tentang implementasi kurikulum 2013 dimensi konsep kurikulum, pengadaan buku, aktivitas belajar dan penilaian pembelajaran. Dari data yang diperoleh disimpulkan bahwa rata-rata dimensi implementasi kurikulum 2013 yang meliputi konsep kurikulum, pengadaan buku, aktivitas belajar, dan penilaian oleh guru di SD Negeri adalah baik. Hal ini dapat dicermati dari respon guru yang diwawancarai dan rekapitulasi angket dengan mean 80,70. Proses pembelajaran yang diobservasi menunjukkan konsep kurikulum sudah mengakomodasi kebutuhan siswa. Kebutuhan siswa diakomodasi, diamati dari perangkat pembelajaran, dan pengembangan materi pembelajaran didasarkan pada kondisi lingkungan, sosial, minat, serta bakat peserta didik.

\section{Implementasi Kurikulum 2013 Ditinjau dari Kompetensi Pedagogik Guru SD Negeri}

a. Hasil wawancara menunjukan bahwa aspek penguasaan karakteristik peserta didik dan aspek fisik, moral, sosial, kultural, emosional, dan intelektual dilakukan melalui pendekatan individu dengan bertanya jawab tentang diri siswa (wawancara) serta mempelajari data-data pribadi peserta didik

Kesimpulan tersebut juga didukung dari hasil observasi yang menunjukkan guru memahami karakteristik peserta didik melakukan pendekatan tanya jawab, memperkenalkan diri, dan mengisi data-data peserta didik. Hasil studi dokumen juga menunjukkan guru kelas memiliki record kondisi siswa berkaitan dengan keadaan fisik, sifat, kompetensi dominan, serta kendalakendala siswa dalam proses belajar.

b. Penguasaan teori belajar dan prinsip-prinsip pembelajaran

Berkaitan dengan penguasaan teori belajar yang diterapkan responden berpendapat bahwa teori belajar Konstruktivisme relevan diterapkan sesuai dengan tuntutan Kurikulum 2013. Hasil wawancara ini sesuai dengan hasil observasi dan studi dokumen guru kelas. 
Kelengkapan dan persiapan guru untuk satu kali proses pembelajaran, umumnya sesuai dengan tuntutan kurikulum. Penerapan teori pembelajaran dan prinsip-prinsip pembelajaran dijabarkan ke dalam Silabus, RPP (Rancangan Pelaksanaan Pembelajaran), Jurnal harian siswa, dan catatan perkembangan siswa.

c. Pengembangan kurikulum terkait dengan mata pelajaran

Pengembangan kurikulum terkait mata pelajaran merupakan proses penerapan kurikulum dengan memodifikasi mata pelajaran menjadi lebih bermakna dalam kehidupan lingkungan peserta didik. Hasil wawancara dengan beberapa guru SD Negeri menghasilkan kesimpulan bahwa pengembangan kurikulum di SD Negeri terkait dengan mata pelajaran dilaksanakan dengan menggali potensi siswa. Potensi kecerdasan, keterampilan, sosial, dan kepribadian dikembangkan sesuai dengan karakter siswa. Kesimpulan tersebut ditriangulasi dengan observasi terhadap kegiatan ekstrakurikuler untuk persiapan O2SN, FL2SN, festival anak sholeh serta kegiatan pengembangan potensi siswa bidang sosial, dan religi. Dengan kegiatan tersebut, potensi kecerdasan akademik, interaksi sosial, kepribadian sesuai etik, estetika seni dan keindahan, dan kinestetik olah tubuh peserta didik dapat dikembangkan serta dapat diamati secara langsung.

d. Penyelenggaraan pembelajaran yang mendidik.

Pembelajaran yang mendidik bermakna pembelajaran yang dalam prosesnya tidak hanya berorientasi pengetahuan namun terbentuknya karakter positif pada peserta didik sebagai imbas dari proses pembelajaran. Hasil wawancara dengan guru kelas SD Negeri menunjukkan bahwa pelaksanaan pembelajaran mendidik diterapkan melalui proses pembelajaran yang menekankan karakter meliputi aspek pengetahuan, keterampilan, dan kepribadian. Hasil observasi menunjukkan guru kelas memberikan punishment dan reward dengan tujuan mendidik siswa agar memahami bahwa hukuman tidak semata ganjaran atas kesalahan yang diperbuat namun juga memaknai nilai kedisiplinan, tanggung jawab dan toleransi dalam proses pembelajaran. e. Memfasilitasi pengembangan potensi dan aktualisasi potensi siswa

Dari hasil wawancara guru SD Negeri dapat disimpulkan bahwa pengembangan potensi siswa dan aktualisasi potensi peserta didik dilakukan dengan melibatkan siswa dalam proses pembelajaran sehingga siswa termotivasi percaya diri, kreatif, dan kritis. Motivasi yang dibangun pada diri peserta didik akan berpengaruh terhadap kerpercayaan diri untuk berkreasi dan berinovasi. Hasil pengamatan menunjukkan hanya $40 \%$ guru SD Negeri memfasilitasi pengembangan potensi siswa dan aktualisasi potensi siswa pada kegiatan pembelajaran. Hal ini diamati dari upaya guru mendukung kegiatan siswa mengikuti lomba-lomba akademik, seni, dan psikomotorik siswa seperti futsal, atletik, senam dan lain-lain. Data tersebut didukung dengan hasil studi dokumentasi dari undangan kegiatan, dan dari laporan pembimbing kegiatan lomba-lomba akademik, seni, dan psikomotorik.

f. Berkomunikasi secara efektif, empatik, dan santun dengan siswa

Membangun komunikasi dengan peserta didik merupakan sebentuk interaksi sosial guru dalam rangka mendidik dan pembiasaan nilainilai kesopanan, kesantunan, serta etika peserta didik dalam proses pembelajaran di sekolah. Hal ini disimpulkan dari wawancara dengan guru SD Negeri dalam kaitannya dengan upaya guru membangun komunikasi yang baik dengan peserta didik sebagai penauladanan dalam berkomunikasi dan membimbing. Hal ini didukung oleh hasil observasi guru ketika membimbing dan mengarahkan siswa untuk dapat berkomunikasi dengan sesama rekan dengan menjadikan guru sebagai model berkomunikasi baik. Guru menerapkan komunikasi empatik dan santun di lingkungan sekolah.

g. Menyelenggarakan penilaian dan evaluasi

Penilaian dan evaluasi merupakan kegiatan untuk mengukur efektivitas pembelajaran dan referensi untuk proses pembelajaran berikutnya. Kesimpulan ini diperoleh sebagai hasil wawancara dengan guru SD Negeri. Hal ini didukung hasil studi dokumen terhadap perangkat pembelajaran serta program remedial dan pengayaan beberapa guru menunjukkan bahwa penilaian 
proses, hasil belajar, dan teknik pembelajaran yang tertuang dalam RPP serta evaluasi berkala seperti Ujian Tengah Semester (UTS) dan ujian semester sudah terlaksana baik di SDN 006 Bengkong.

h. Memanfaatkan penilaian dan evaluasi untuk kepentingan pembelajaran

Penilaian dan evaluasi sangat bermanfaat bagi peserta didik, guru, dan sekolah. Melalui penilaian dan evaluasi, diketahui sejauh mana kemampuan siswa dalam mengikuti pembelajaran dan mengetahui kepuasan mereka setelah memperoleh hasil penilaian. Selain itu, penilaian dapat menjadi tolak ukur perbaikan pengalaman belajar siswa. Wawancara dengan guru SD Negeri dilakukan untuk mengetahui pemanfaatan hasil penilaian dan evaluasi di SD Negeri. Triangulasi guna memperkuat pernyataan-pernyataan wawancara dilakukan dengan observasi dan studi dokumen. Observasi dilakukan pada kegiatan penguatan karakter. Guru mengapresiasi siswa yang memberikan tauladan bagi siswa lainnya tentang nilai dan sikap sosial. Studi dokumentasi diambil dari rapat dewan guru dan kepala sekolah tentang penguatan karakter pada siswa melalui proses pembelajaran.

i. Melakukan tindakan reflektif untuk meningkatkan kualitas pembelajaran

Kegiatan refleksi adalah sebentuk kegiatan respon siswa terhadap guru setelah mengikuti rangkaian proses pembelajaran dalam jangka waktu tertentu. Wawancara dengan perwakilan guru SD Negeri untuk mengetahui manfaat setelah pembelajaran. Triangulasi dilakukan dengan studi dokumentasi pada laporan Penelitian Tindakan Kelas (PTK) guru-guru SD Negeri.

\section{Implementasi Kurikulum 2013 ditinjau dari Penguasaan TIK Guru.}

Penguasaan Teknologi Informasi dan Komunikasi (TIK) dalam implementasi Kurikulum 2013 menjadi kompetensi yang mau tidak mau harus dimiliki guru sebagai media penting bagi guru melaksanakan tugas dan fungsinya. TIK yang berkembang cepat dan dinamis perlu disikapi guru dengan mengetahui dan menggunakan TIK tersebut sebagai sarana pendukung tugas sekaligus media pembelajaran efektif. a. TIK yang digunakan dalam kegiatan pembelajaran.

Hampir seluruh guru kelas menyatakan hal yang sama tentang TIK yang digunakan untuk proses pembelajaran. Hasil observasi menunjukan bahwa teknologi informasi yang digunakan guru-guru SD Negeri adalah laptop, PC, audio set (speaker), jaringan Internet, dan proyektor (infocus).

b. Kegiatan guru bagi pengembangan bahan ajar dengan menggunakan TIK

Di bidang pendidikan, penguasaan TIK oleh guru bermanfaat bagi pengembangan bahan ajar dan strategi pembelajaran. Hasil wawancara menunjukan guru dapat menggunakan TIK sebagai sarana komunikasi pada proses pembelajaran di kelas dan dapat dimanfaatkan sebagai tool pengirim tugas, materi pembelajaran, penilaian, dan diskusi. Hal tersebut direalisasikan dengan memberikan materi pembelajaran baik menggunakan email, e-learning, maupun blog. Hasil wawancara tersebut didukung oleh hasil observasi terhadap tayangan-tanyangan yang ditampilkan pada proses pembelajaran. Begitu juga hasil studi dokumentasi terhadap Rencana Pelaksanaan Pembelajaran (RPP), guru mencantumkan materi pembelajaran yang dilengkapi dengan slide dan video pembelajaran.

c. Bentuk penggunaan teknologi informasi dan komunikasi

Pemanfaatan TIK pada proses pembelajaran dilakukan dengan menggunakan TIK sebagai media pembelajaran dan pengembangan materi dengan penugasan kepada siswa. Semua bentuk pengembangan materi pembelajaran dipengaruhi kreativitas dan kemampuan guru mengoptimalkan TIK. Dari wawancara dengan bahwa guru-guru SD Negeri diperoleh kesimpulan bahwa guru sudah menggunakan program TIK yang menunjang pembelajaran langsung (real). Hal ini dikuatkan dengan hasil observasi kegiatan pembelajaran di kelas. Hampir semua kelas dilengkapi projektor dan semua guru memiliki laptop untuk mendukung kegiatan pembelajaran di kelas melalui penggunaan beberapa program komputer yang dikuasai guru bersangkutan. 


\section{KESIMPULAN}

Analisis terhadap kompetensi pedagogik guru dalam implementasi Kurikulum 2013 disimpulkan bahwa kompetensi pedagogik guru SD Negeri sudah baik dalam penerapan Kurikulum 2013,

1. Penguasaan karakteristik peserta didik dan aspek fisik, moral, sosial, kultural, emosional dan intelektual dilaksanakan guru melalui pendekatan personal guru terhadap peserta didik.

2. Penguasaan teori belajar dan prinsip-prinsip pembelajaran cenderung menerapkan teori belajar konstruktivisme dengan model serta metode variatif.

3. Pengembangan kurikulum terkait mata pelajaran dengan mengembangkan standar kompetensi dan kompetensi dasar serta memperhatikan karakteristik dan potensi siswa.

4. Penyelenggaraan pembelajaran yang mendidik dilakukan melalui penauladanan, pembimbinngan, dan pengarahan peserta didik tentang nilai, norma, dan karakteristik.

5. Memfasilitasi pengembangan potensi dan aktualisasi potensi siswa dilakukan dengan menerapkan pendekatan pembelajaran saintifik.

6. Berkomunikasi efektif diterapkan melalui komunikasi bersifat komunikatif sebagai sarana pembelajaran.

7. Penilaian dan evaluasi pada implementasi Kurikulum 2013 dilaksanakan secara holistik. Holistik dipahami sebagai penilaian aspek sikap, pengetahuan, dan keterampilan dilaksanakan bersamaan sesuai dengan kondisi.

8. Pemanfaatan penilaian dan evaluasi untuk kepentingan pembelajaran dijadikan sebagai acuan pencapaian hasil belajar.

9. Melakukan tindakan reflektif guna meningkatkan kualitas pembelajaran. dilakukan dengan membandingkan pencapaian hasil belajar dengan tindakan, perlakuan guru atau pelaksanaan rancangan pelaksanaan pembelajaran (RPP).

Implementasi Kurikulum 2013 ditinjau dari kompetensi penguasaan TIK pada SD Negeri, cukup baik dilihat dari 3 (tiga) dimensi kompetensi penguasaan TIK guru, sebagai berikut:
1. Teknologi informasi dan komunikasi yang digunakan guru dalam kegiatan pembelajaran adalah teknologi berbasis elektronik.

2. Kegiatan guru SD Negeri Bengkong dalam pengembangan bahan ajar menggunakan TIK diintegrasikan dalam Rancangan Pelaksanaan Pembelajaran (RPP).

3. Pemanfaatan TIK di SD Negeri adalah dengan penggunaan TIK sebagai media pembelajaran, pengembangan materi, penugasan, akses sumber belajar via internet, presentasi menggunakan slide power point, serta pembuatan video baik untuk aktivitas pembelajaran maupun materi pembelajaran.

\section{SARAN}

Saran-saran yang diajukan adalah sebagai berikut.

1. Kepala Sekolah hendaknya berupaya meningkatan kompetensi pedagogik guru. Upaya ini dilakukan dengan sinergi Kelompok Kerja Guru (KKG) sebagai team work guna meningkatkan, membimbing, dan memantapkan kompetensi pedagogik guru secara berkelanjutan.

2. Guru diharapkan selalu update perkembangan TIK khususnya teknologi yang bermanfaat besar terhadap pengetahuan dan pembelajaran di sekolah.

3. Guru harus dimotivasi memiliki rasa ingin tahu, dan banyak tahu penggunaan TIK serta dapat memotivasi diri berkemampuan mengoptimalkan TIK.

4. Dinas pendidikan hendaknya memberikan pembekalan, pelatihan, ataupun workshop bagi guru memanfaatkan TIK secara terus menerus.

\section{REFERENSI}

Anggara, S. (2014). Kebijakan Publik. Bandung: CV Pustaka sety.

Bughin, J., Manyika, J., \& Woetzel, J. (2016). MGI The Age of Analytics: Competing in a Data-Drivel World.

Hasan, D. (2015). Kebijakan dan Pengenbangan Kurikulum Pendidikan Dasar. Jakarta: Modul MPDR105 Universitas Terbuka.

Melianasari, D. (2015). Layanan Bimbingan Kelompok Teknik Modeling dalam 
Meningkatkan Kedisiplinan Siswa. In Jurnal Pedagogia (Vol. 2). Bandung: Universitas Pendidikan Indonesia.

Mulyasa, E. (2008). Menjadi Guru Profesional Menciptakan Pembelajaran Kreatif dan Menyenangkan. Bandung: Remaja Rosdakarya.

Muzamiroh, L. . (2013). Kupas Tuntas Kurikulum 2013 (Kelebihan dan Kekurangan Kurikulum 2013). Kota Pena.

Niarsa, A. (2013). Studi Kemampuan Guru Dalam Mamanfaatkan Media Pembelajaran Berbasis Teknologi Informasi dan Komunikasi (TIK) di SD Negeri 01 Ledok Kecamatan Sambong Kabupaten Blora. Universitas Negeri Semarang.
Nugroho, D, R. (2003). Kebijakan Publik: Formulasi, Implementasi, dan Evaluasi J. Jakarta: Elex Media Komputindo.

Patton, \& Sawicki. (1993). Basic Methods of Policy Analysis and Planning. Prentice Hall: Michigan University.

Syaukani, D. (2004). Otonomi Daerah Dalam Negara Kesatuan. Yogyakarta: Pustaka Pelajar.

Undang-Undang Nomor 20 Tahun 2003 tentang Sistem Pendidikan Nasional.

Wibowo. (2007). Manajemen Kinerja. Jakarta: Raja Grafindo Parsada. 